\title{
Controlling Factors of the Stable Isotope Composition in the Precipitation of Islamabad, Pakistan
}

\author{
Shakir Hussain,, Song Xianfang,, Iqtidar Hussain, ${ }^{1,3}$ Liu Jianrong, ${ }^{1}$ Han Dong Mei, \\ Yang Li Hu, ${ }^{1}$ and Wei Huang ${ }^{4}$ \\ ${ }^{1}$ Key Laboratory of Water Cycle and Related Land Surface Processes, Institute of Geographic Sciences and Natural Resources Research, \\ Chinese Academy of Sciences, Beijing 100101, China \\ ${ }^{2}$ Department of Environmental Science, Karakoram International University, Gilgit 15100, Pakistan \\ ${ }^{3}$ Key Laboratory of Tibetan Plateau Environment Changes and Land Surface Processes, Institute of Tibetan Plateau Research, \\ Chinese Academy of Sciences, Building 3, Courtyard 16, Lin Cui Road, Chaoyang District, Beijing 100101, China \\ ${ }^{4}$ Research School of Arid Environment and Climate Change, Lanzhou University, 222 South Tianshui Road, \\ Lanzhou, Gansu 730000, China
}

Correspondence should be addressed to Song Xianfang; songxf@igsnrr.ac.cn

Received 1 May 2015; Revised 28 July 2015; Accepted 11 August 2015

Academic Editor: Rossella Ferretti

Copyright (C) 2015 Shakir Hussain et al. This is an open access article distributed under the Creative Commons Attribution License, which permits unrestricted use, distribution, and reproduction in any medium, provided the original work is properly cited.

Significant temporal variations in $\delta^{18} \mathrm{O}$ and deuterium isotopes were found in the rainfall water of Islamabad, Pakistan, over a 15-year period (1992-2006). The data were obtained from the International Atomic Energy Agency/Global Network of Isotopes in Precipitation (IAEA/GNIP) database, and statistical correlations were investigated. In particular, this study provides the first detailed analysis of GNIP data for Islamabad. Both dry (1999-2000) and wet years (1994, 1997, and 2000) were chosen to investigate the correlations between precipitation amount, vapor flux, and temperature. We observed obvious differences between the dry and wet years and among seasons as well. Long-term features in the isotope composition agreed with the global meteorological water line, whereas short-term values followed rainfall amounts; that is, a total of $72 \%$ of the precipitation's isotopic signature was dependent on the rainfall amount, and temperature controlled $73 \%$ of the isotopic features during October to May. The lower $d$-excess values were attributed to conditions during the spring season and a secondary evaporation boost during dry years; precipitation originating from the Mediterranean Sea showed high $d$-excess values. Overall, the results of this study contribute to the understanding of precipitation variations and their association with water vapor transport over Islamabad, Pakistan.

\section{Introduction}

Monsoons and western disturbances are the most significant features of the South Asian climate, and both prevail prominently in the southern Himalayas. Islamabad, which is located in the foothills of the lesser Himalayas, receives rainfall from both of these phenomena, and it is representative of the northern high-rainfall region of Pakistan. The monsoon season involves the seasonal reversal of wind direction; this phenomenon transports water widely on a mesoscale and is an important carrier of precipitation over South Asia [1] The main sources of South Asian atmospheric moisture are the Bay of Bengal and the Arabian Sea, as moist low-level warm winds carry moisture into hotter inland areas [2].
The agriculture based economy of this region is vulnerable to interannual and seasonal monsoon oscillations, and floods and droughts occur in Pakistan following the migration of the monsoon trough.

The relationship between hydrogen and oxygen isotopes in water has been investigated by many researchers [3-9] and recognized as a complete discipline of hydrological science [10]. The meteoric water line $\left(\delta \mathrm{D}=8 \delta^{18} \mathrm{O}+10\right)$, as expressed by Craig [4], is a globally accepted scale for measuring isotopic deviations in rainfall water. The conservative nature of water isotopes makes them effective tracers of atmospheric moisture origins and circulation. Distribution patterns and variability of atmospheric circulation have a considerable 
effect on the isotopic features of precipitation, as well as meteorological parameters such as rainfall amount, temperature, and soil and atmospheric moisture. A remarkable number of studies have been carried out using environmental isotopes in Europe and North America, but studies from South Asia are rare. Datta et al. [11] revealed significant temporal variations in isotopic precipitation features for Delhi, and Sengupta and Sarkar [12] confirmed with isotopes that the Bay of Bengal and the Arabian Sea act as moisture sources for the subcontinent.

There are currently no studies on the different temporal variations, trends, and moisture sources for rain water in Pakistan from an isotopic perspective. The International Atomic Energy Agency/Global Network of Isotopes in Precipitation (IAEA/GNIP) is the world's largest project on isotopic hydrology, and its main database [13] is used globally to study isotopes in rainfall water; however, Pakistan has only one GNIP station at Islamabad. Although the GNIP does not provide data at a high enough resolution to determine all the controlling dynamics of isotope signatures in this region, we were able to obtain 15 years (1992-2006) of precipitation isotope data and use it to investigate the controlling factors and isotopic compositions of rainfall water in Islamabad. Therefore, this study provides the first detailed analysis of GNIP data for Islamabad, with a focus on precipitation controlling factors, sources, and variations on different temporal scales. Our results have the potential to enhance understanding of the temporal variation and sources of precipitation for Pakistan, Islamabad.

\section{Study Area}

Meso- and microscale convective phenomena are the result of low temperatures over the tropics. The border of Pakistan is defined by latitudes of $23^{\circ} 35^{\prime} \mathrm{N}-37^{\circ} 05^{\prime} \mathrm{N}$ and longitudes of $60^{\circ} 50^{\prime} \mathrm{E}-77^{\circ} 50^{\prime} \mathrm{E}$, which falls within the extra tropics that demarcate the limits of easterly wind patterns in South Asia. Much of Pakistan is covered by arid to semiarid regions, excluding the humid belt along the southern foothills of the Himalayas [14]. The northern region of South Asia receives more precipitation due to the orographic uplift of the Himalayas [15]. This investigation has focused on Islamabad, which lies in the foothills of the lesser Himalayas (Margalla Hills). Air masses shed moisture on the windward side because of the influence of orographic uplift, which in this case involves the perpendicular interaction of a southerly wind with the inverted " $V$ " shape valley in the foothills of the southern Himalayas during favorable environmental conditions [16]. In spring season, northwestern westerlies bring low amounts of moisture from the elevated lands of Iran and Afghanistan over the northern part of South Asia (Islamabad) (Figure 1). Continuous transport of moist air from the Arabian Sea and the Bay of Bengal causes moisture to accumulate along the southern Himalayas during the summer monsoon. The underlying summer rainfall phenomenon over Pakistan involves the incursion of southwesterly winds from the Arabian Sea and the monsoon depression, which often forms in the northern Bay of Bengal and occasionally over the northern Arabian Sea within the monsoon trough. Northward migration of the monsoon trough is the cause of meteorological floods such as those seen in 2001 [16] and 2010 [17], and this brings heavy rainfall over the southern Himalayas. The northern Bay of Bengal and the western subcontinent provide the eastern and western limits for the monsoon trough, respectively. The monsoon onset (cyclonic storms in the Arabian Sea) reaches Pakistan after mid-June, about a month after it prevails over Western Ghats (India). Uplifting of lower tropospheric tropical moist air embedded under the cold air of a westerly creates highly unstable atmospheric conditions that can lead to extreme precipitation events.

Western disturbances originating from the Mediterranean Sea and the Atlantic Ocean are the main carriers of precipitation in winter. Notable rainfall is carried to the northern area (Islamabad) of Pakistan after following a path over inland Asia. In the southern Himalayas [18], western disturbances moving in the opposite direction to the summer monsoon contribute to the generation of the "monsoon break" by pushing the monsoon trough towards the Himalayas and attracting more precipitation with the resulting intensified surface low. The "active" and "break" monsoon phases are opposites in a dipole system that occurs more frequently during extreme climate phases. A high level of rainfall occurs in the humid northern region of Pakistan, whereas the southwestern and central parts of Baluchistan and the northwestern parts of Sindh remain dry for more than $50 \%$ of the time; these regions are highly vulnerable to drought [19]. The onset of the summer monsoon typically begins on 1 June with rainfall over Kerala, southwest India, where the Bay of Bengal branch reaches over the western Himalayas while passing through the Indo-Gangetic Plain in between the Himalaya and Deccan plateau. A high mean temperature prevails in the southern part of the country, which is dry compared with the northern half.

According to the Köppen-Geiger classification [20], Islamabad's hot, humid summers and generally mild winters place it in the moderate seasonality (CWA) category. Annual mean temperatures and precipitation are $21.3^{\circ} \mathrm{C}$ and $1201 \mathrm{~mm}$, respectively, and these values typically vary by $30^{\circ} \mathrm{C}$ and $330 \mathrm{~mm}$, respectively, which is indicative of a temperate climate. Islamabad experiences clear seasonality with four distinct seasons: spring (March-May), summer (June-August), autumn (September-November), and winter (DecemberFebruary), and each season has an almost unique water vapor circulation pattern (Figure 2). High temperatures, dry air, and dust storms jointly shape the spring season (premonsoon), which is usually dominated by drought. During the summer monsoon, sufficient rainfall decreases the effects of scorching sun, but the high air relative humidity rate increases the perceived temperature.

In general, precipitation follows temperature changes (Figure 1), except in spring, which is when enriched isotope values were observed. To some extent, the ENSO (El Niño Southern Oscillation) affects seasonal rainfall in Pakistan, as precipitation increases in the north and shifts westward [19]. The increasing amount of precipitation with the onset of the summer monsoon will exacerbate annual and seasonal 


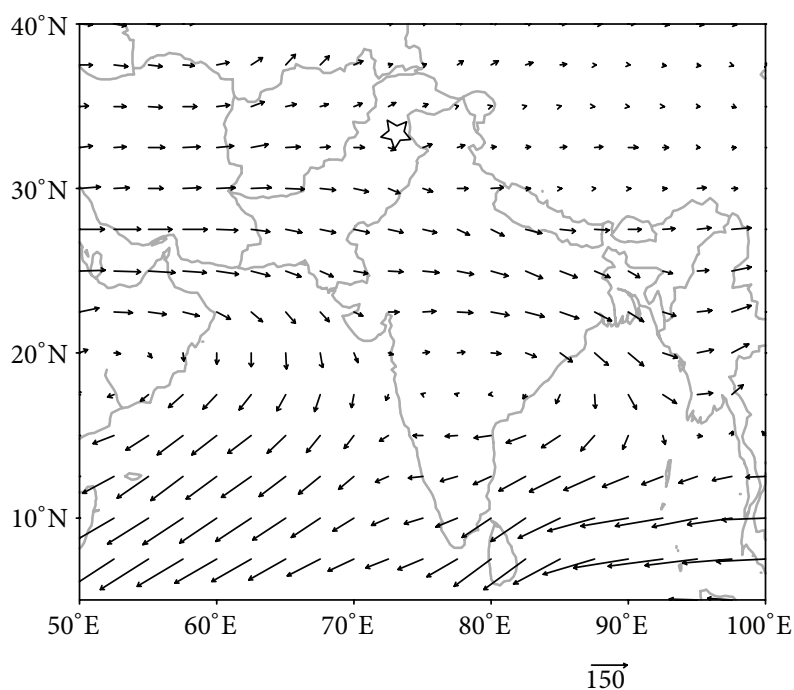

(a)

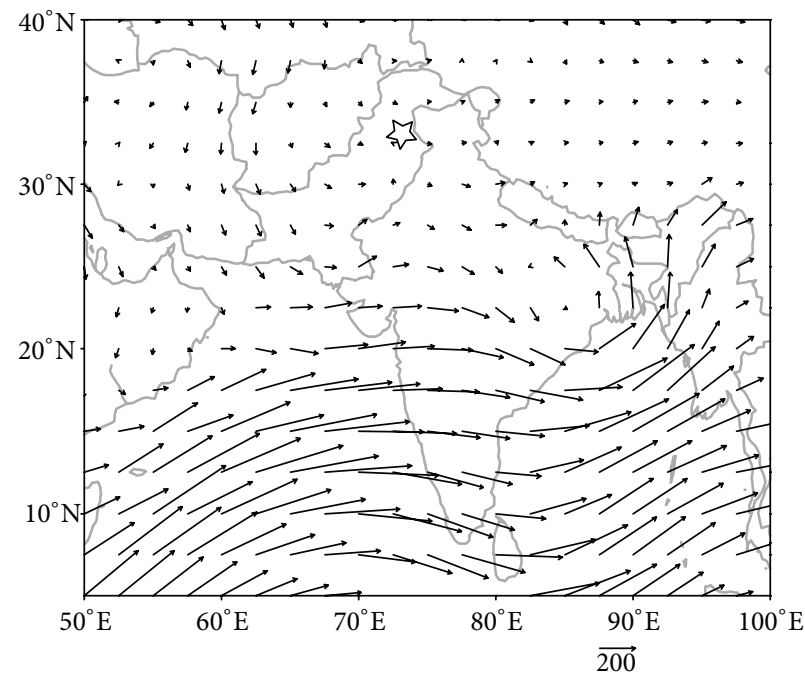

(c)

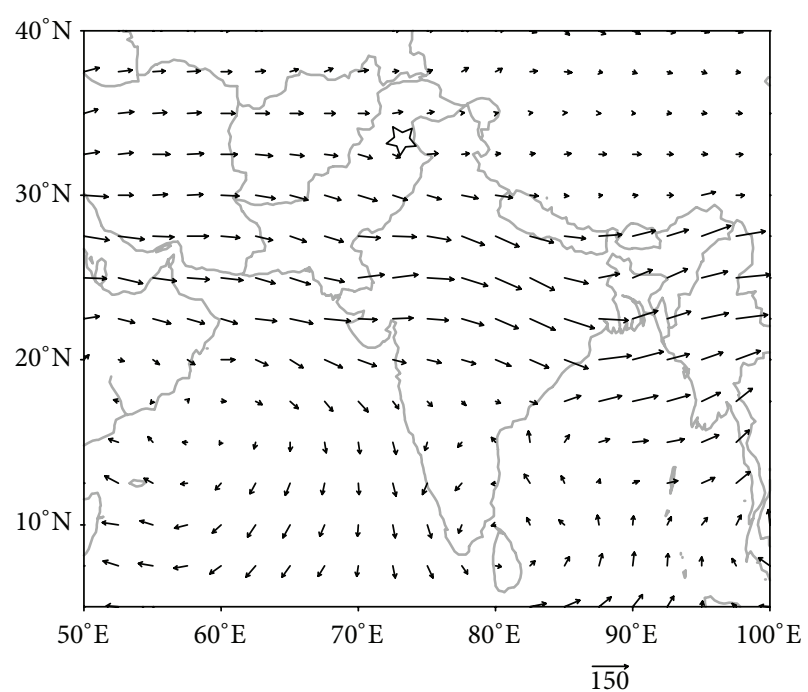

(b)

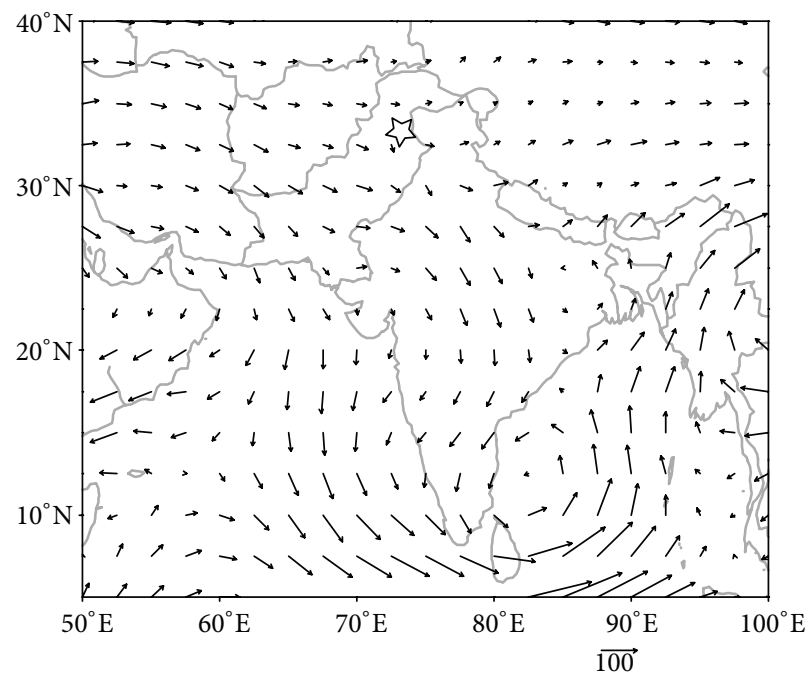

(d)

FIGURE 1: Seasonal vertically integrated water vapor flux (300-1000 hpa) from 1992 to 2006 during (a) winter, (b) spring, (c) summer, and (d) autumn (units: $\left.\mathrm{kg} \cdot \mathrm{m}^{-1} \cdot \mathrm{s}^{-1}\right)$. A star is showing Islamabad $\left(33.65^{\circ} \mathrm{N}, 73.26^{\circ} \mathrm{E}\right)$.

isotopic variations. During 1989-2013, Islamabad experienced average annual precipitation levels and temperatures of $1201 \mathrm{~mm}$ and $21.3^{\circ} \mathrm{C}$, respectively. Above-average rainfall occurred in 1994, 1997, and 2001, whereas an annual rainfall of only 781, 802, and $872 \mathrm{~mm}$ occurred during 1999, 2000, and 2005, respectively. On 23 July 2001, $620 \mathrm{~mm}$ of rainfall was recorded in just 10 hours, which was the highest recorded rainfall in a 24-hour period over the past 100 years [16]. The most severe national-scale droughts over the last 100 years occurred in 1999 and 2000 [16, 21].

\section{Materials and Statistical Procedures}

For this investigation, daily meteorological data (1992-2006) were provided by the Pakistan Metrological Department. These meteorological data were statistically correlated with precipitation isotope data for Islamabad, which was obtained from the IAEA/GNIP database (http://www.univie.ac.at/ cartography/project2/wiser/index.php). To determine the possible sources of rainfall for Islamabad, we used the hybrid Single-Particle Lagrangian Integrated Trajectories (HYSPLIT) ARL trajectory tool database of the National Oceanic and Atmospheric Administration, NOAA (http://www.arl.noaa .gov/ready/hysplit4.html). Weekly trajectories were computed for 300,600, 850, and 900 hpa because the rainfall was assumed to have come from these altitudes to catch the two main precipitation systems, that is, summer monsoon and western disturbances. Data for both dry (1999, 2000) $[16,21]$ and wet $(1994,1997$, and 2001) years were determined on the basis of climatological annual rainfall amounts. The monthly geopotential height, winds, and specific humidity at the corresponding pressure levels were obtained from the National Centre for Environmental Prediction-National Centre for Atmospheric Research (NCEP-NCAR) reanalysis 


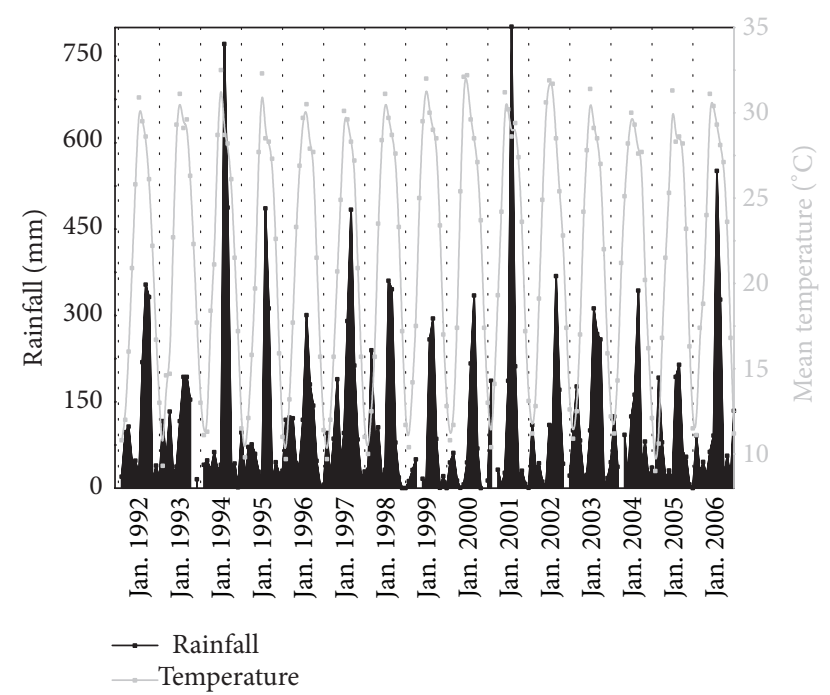

FIGURE 2: Mean monthly rainfall and temperature for Islamabad between 1992 and 2006.

dataset [22], and these data were used to calculate the vertically integrated vapor flux. The pressure levels below the surface pressure as a result of topography were omitted when the water vapor fluxes were computed. The weighted means of meteorological and rainfall water isotope data were calculated by the method described in IAEA [23].

\section{Results and Discussion}

\subsection{Relationships of the Meteorological Parameters and Water Vapor Sources to the Stable Isotopes}

4.1.1. Local Meteoric Water Line and Water Vapor Source. Owing to the tropical climate, Islamabad experiences clear seasonality and moisture sources vary on seasonal scales. In accordance with these changes, we found that $\delta^{18} \mathrm{O}$ values varied from -19.28 to 9.77 and $\delta \mathrm{D}$ values varied from -147.25 to 72.96 . The annual weighted mean values of $\delta^{18} \mathrm{O}$ and $\delta \mathrm{D}$ in rainfall water of Islamabad from 1992 to 2006 showed a strong correlation $\left(R^{2}=0.95\right)$ (Figure 3 ). This relationship resembles that found for rainfall water at a Northern Hemisphere continental station by Dansgaard $\left(\delta \mathrm{D}=8.1 \delta^{18} \mathrm{O}+11\right)$ [24], though the results deviated slightly from the global meteoric water line (GMWL) $\left(\delta \mathrm{D}=8 \delta^{18} \mathrm{O}\right.$ $+10)$. The local meteoric water line (LMWL) of Islamabad has a slope less than 8 , which is presumably influenced by its location (the continental effect), and only a few data points were located above the GMWL, possibly as a result of moisture recycling. In general, most of the data plotted below the GMWL, and these data were likely affected by increased evaporation loss. Most of the stable isotope values were along the GMWL, which is indicative of condensation processes involving Rayleigh distillation [4]. The data showed strong seasonality, and inland behavior of $\delta^{18} \mathrm{O}$ and $\delta \mathrm{D}$ values displayed dispersal patterns with the increasing temporal resolution.

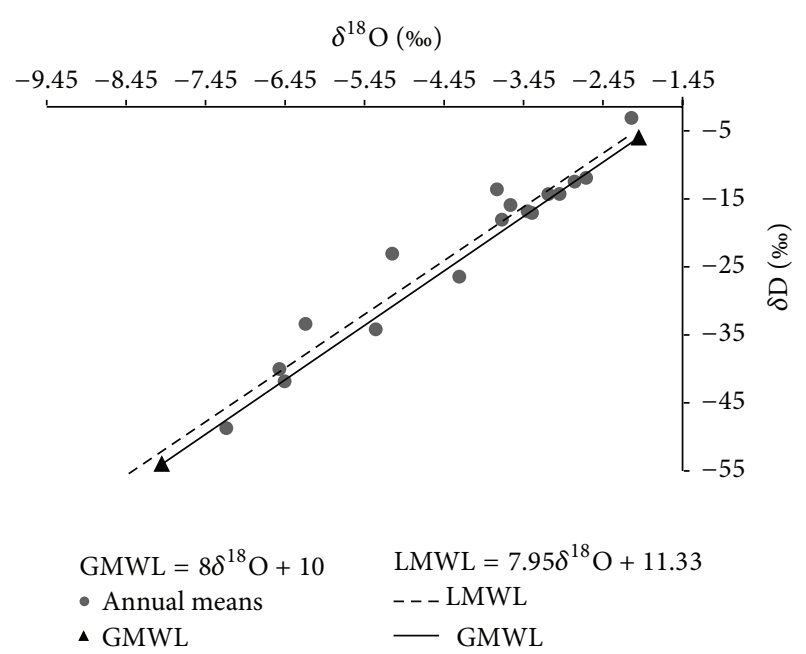

Figure 3: Local meteoric water line (LMWL) (dashed line) for Islamabad from the annual weighted mean data (1992-2006) and comparison to the global meteoric water line (GMWL) (solid line).

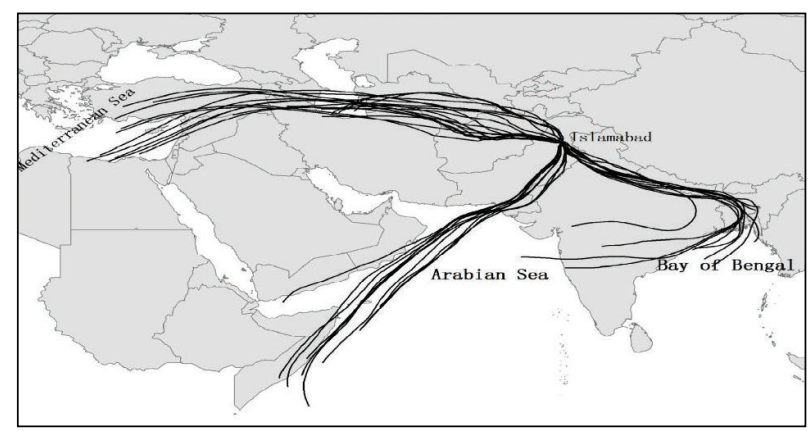

Figure 4: Back trajectories of air masses of Islamabad $\left(33.65^{\circ} \mathrm{N}\right.$, $\left.73.26^{\circ} \mathrm{E}\right)$.

The back trajectories (Figure 4), which are only approximations of the general air mass origins of our study area, changed with respect to time; these data helped us to understand how precipitation sources affected the stable isotope composition of the rainfall water.

Specifically, in winter, the Mediterranean Sea air masses have to travel a long distance inland to reach Islamabad compared to the air masses in summer originating from Indian Ocean. Long distance travel with low temperature makes the winter precipitation more depleted (Figure 7). Input from these air masses results in kinetic fractionation marked by the specific sources of water vapor. In summer, the air masses come from the warm and humid Indian Ocean, and, in this region, there is massive Himalayan river input into the Bay of Bengal. The river water input signal became visible during the months of August and September in the analyzed dataset, as indicated by the depleted stable isotope values [25] (Figure 6). Furthermore, cyclones in the Bay of Bengal are more frequent than in the Arabian Sea, which facilitates this region's large contributions to the rainfall over northern Pakistan [26]. Gat et al. [27] revealed that lower relative humidity and more evident kinetic isotope fractionation 
TABLE 1: Long-term annual multiple correlation of $\delta^{18} \mathrm{O}$ with precipitation, temperature, and relative humidity.

\begin{tabular}{lcccc}
\hline & Precipitation & Temperature & RH & $\delta^{18} \mathrm{O}$ \\
\hline Precipitation & 1 & & & \\
Temperature & 0.33 & 1 & & \\
$\mathrm{RH}$ & 0.65 & 0.41 & 1 & \\
$\delta^{18} \mathrm{O}$ & 0.48 & 0.59 & 0.51 & 1 \\
\hline
\end{tabular}

during evaporation from close basins like the Mediterranean Sea are associated with higher $d$-excess. Consequently, vapor originating from continental basins can alter the original oceanic signatures $[10,28]$.

Deuterium excess offers another opportunity to investigate the vapor sources. Notably, winter precipitation of Islamabad comes from the Mediterranean Sea, which has a high $d$-excess value, thus confirming the results of Gat et al. [27], who used such data to depict distinct conditions of vapor formation and additions of inland water sources during passage through inland Asia. The humid Indian Ocean air masses reach Islamabad along two different paths (Figure 4). The first path [1] involves air masses that originate from the Arabian Sea and travel over central India; the second path [2] involves air masses that travel along the southern Himalayas from the Bay of Bengal. The warm and humid surroundings of the Indian Ocean are the main cause for the lower $d$ excess values during the summer monsoon. The precipitation amount with $d$-excess is plotted in Figure 13. Overall, we have found that the wet years have higher $d$-excess values than dry years, thus confirming that secondary evaporation took place either below the clouds or within the sampling device.

4.1.2. Correlation between Meteorological Parameters and $\delta^{18} O$. Dansgaard [24] and Rozanski et al. [29] found a strong inverse relation between the rainfall amount and $\delta^{18} \mathrm{O}$ in tropical regions. This relation varied with respect to the time series and local precipitation pattern.

The data shown in Figure 6 could not explain the trends during the months of January and February, where $\delta^{18} \mathrm{O}$ values were more depleted than those in August, thus indicating that the rainfall amount is not the sole controlling factor of $\delta^{18} \mathrm{O}$ in the study region. Local climate variations are often interpreted in terms of temperature or precipitation amounts via paleoclimate proxies of stable isotopes [24]. Temperature is the key controlling parameter of $\delta^{18} \mathrm{O}$ (Table 1 ) showing the highest correlation $\left(r^{2}=0.59\right)$ on annual scale. Figure 7 shows the long-term monthly $\delta^{18} \mathrm{O}$ and temperature explaining the most depleted $\delta^{18} \mathrm{O}$ in the months of January and February following the lowest temperature and from October to May $73 \%$ of $\delta^{18} \mathrm{O}$ is defined by temperature. $\delta^{18} \mathrm{O}$ enrichment of precipitation during hot and dry atmospheric conditions prevailed during the premonsoon period, which is when there is high evaporation of falling raindrops, and the highest enriched $\delta^{18} \mathrm{O}$ value (41.41) was observed in June 2006 when the monsoon onset was delayed.

The relative humidity continuously increased from June to August, and intense and frequent rainfall events slightly
TABLE 2: Annual weighted mean of rainfall water isotopes from Islamabad.

\begin{tabular}{lcc}
\hline Time frame & \multicolumn{1}{c}{ Relationship } & Correlation \\
\hline 1999-2000 & $\delta \mathrm{D}=7.97 \delta^{18} \mathrm{O}+8.73$ & $R^{2}=0.90$ \\
1994, 1997, and 2001 & $\delta \mathrm{D}=6.23 \delta^{18} \mathrm{O}+9.91$ & $R^{2}=0.98$ \\
$1992-2006$ & $\delta \mathrm{D}=7.89 \delta^{18} \mathrm{O}+11.05$ & $R^{2}=0.95$ \\
\hline
\end{tabular}

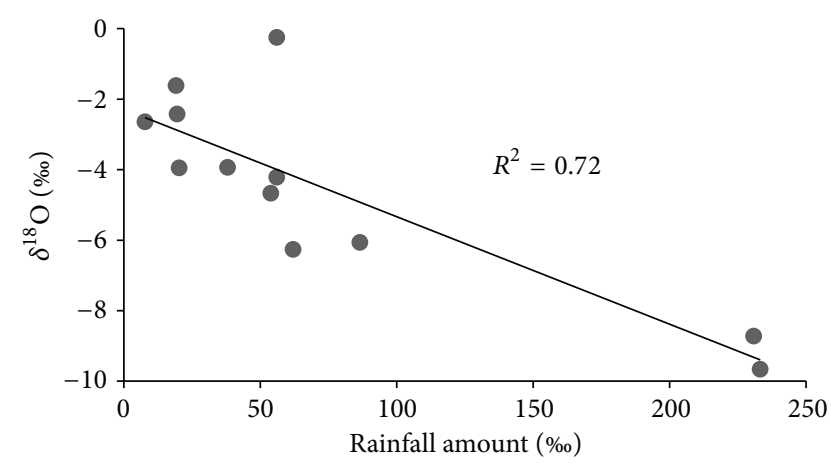

FIGURE 5: Relationship between yearly weighted rainfall amount and $\delta^{18} \mathrm{O}$ of Islamabad.

decreased the temperature, which means that a secondary evaporation factor could decrease during this time. Additionally, August is the peak month of precipitation from the relatively depleted Bay of Bengal [25] cyclones, and this region contributes more precipitation than the Arabian Sea branch. Hence, the resultant $\delta^{18} \mathrm{O}$ values were further depleted in August.

4.2. Temporal Signature of Stable Isotopes. The reversal of wind following the migration of the Intertropical Convergence Zone is known as the South Asian monsoon. The seasonality in Islamabad from this phenomenon can be clearly seen in the stable isotope composition. The seasonal enrichment of $\delta^{18} \mathrm{O}$ and $\delta \mathrm{D}$ increased in the following way: summer < autumn $<$ winter $<$ spring (Figure 8). Seasonal variations were prominent in the monthly isotopic composition data. The nature of South Asian precipitation has been highly dynamic; it has changed on daily to decade long scales in the past and an increasing number of extreme events have been recorded [30]. Besides the monthly and seasonal signals, the stable isotope data also reflect differences between wet and dry years (Table 2). The period 1999-2000 was associated with the worst country level drought in the history of Pakistan $[16,21]$. As we have found, the correlation coefficient between rainfall water and $\delta^{18} \mathrm{O}$ was $R^{2}=0.72$ (Figure 5). Rainfall water $\delta^{18} \mathrm{O}$ of Islamabad clearly showed large differences between the wet and dry years (Figure 9), and, to illustrate these differences (Figure 10), we have calculated the composite water vapor flux on a seasonal scale for these two years because South Asia experiences a peculiar reversal of the seasonal wind direction, as discussed earlier. We observed anomalous behavior of the water vapor flux in all seasons as the drought was captured on the annual scale, and differences were noted in the pre-, post-, and within-monsoon seasons. 


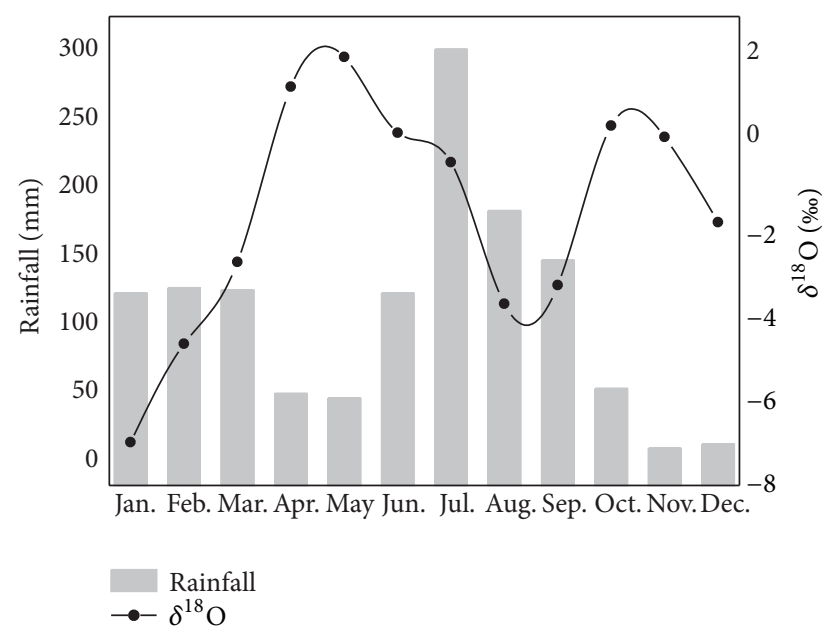

FIGURE 6: Average monthly variation of rainfall and $\delta^{18} \mathrm{O}$ of Islamabad (1992-2006).

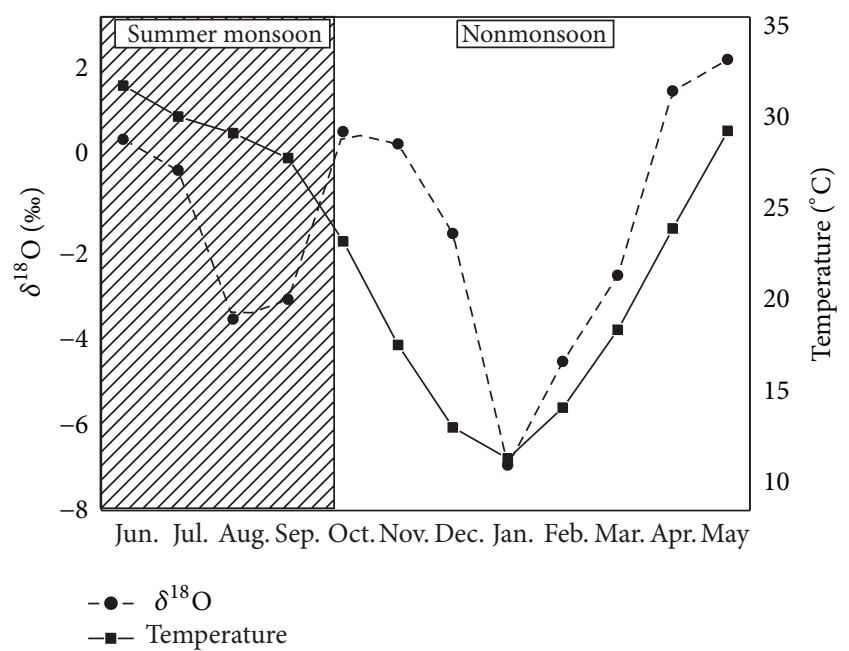

FIGURE 7: Average monthly variation of temperature and $\delta^{18} \mathrm{O}$ of Islamabad (1992-2006).

Figure 10(a) depicts the northward anomalous movement of water vapor from the Bay of Bengal and towards west Asia from the Arabian Sea near the Gulf of Oman. Both movements are in opposition to the climatological pattern of South Asian wind circulation, which brings in more precipitation during the winter season of wet years. Normally, the spring season is the transition phase where the western disturbance influence switches to the summer monsoon, and because of this, the least amount of rainfall occurs during this season. We observed a normal wind flow towards Pakistan from west Asia in the winter, but the data in Figure 10(b) do not agree with this behavior, and the winds heading towards Pakistan from the Arabian Peninsula show noticeable changes in wind direction. In wet years, continental monsoon depressions increased the transport of moist air from the Indian Ocean to the southwestern Himalayas (Pakistan) (see Figure 10(c), where orographic uplift plays a key role in the rainfall event during the southwest monsoon). In dry years, $\delta^{18} \mathrm{O}$ values

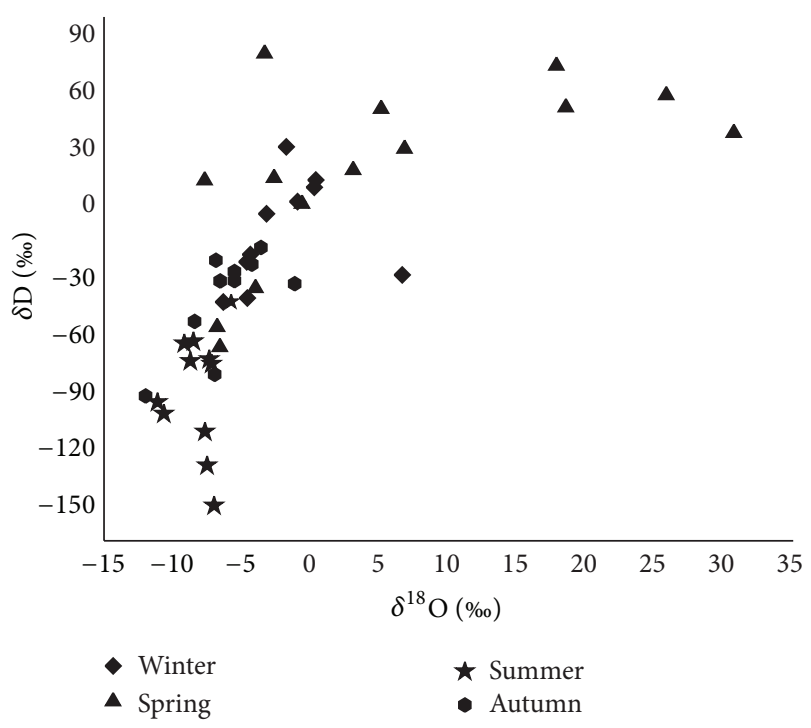

FIgURE 8: Seasonal isotopic variation in the rainfall water of Islamabad.

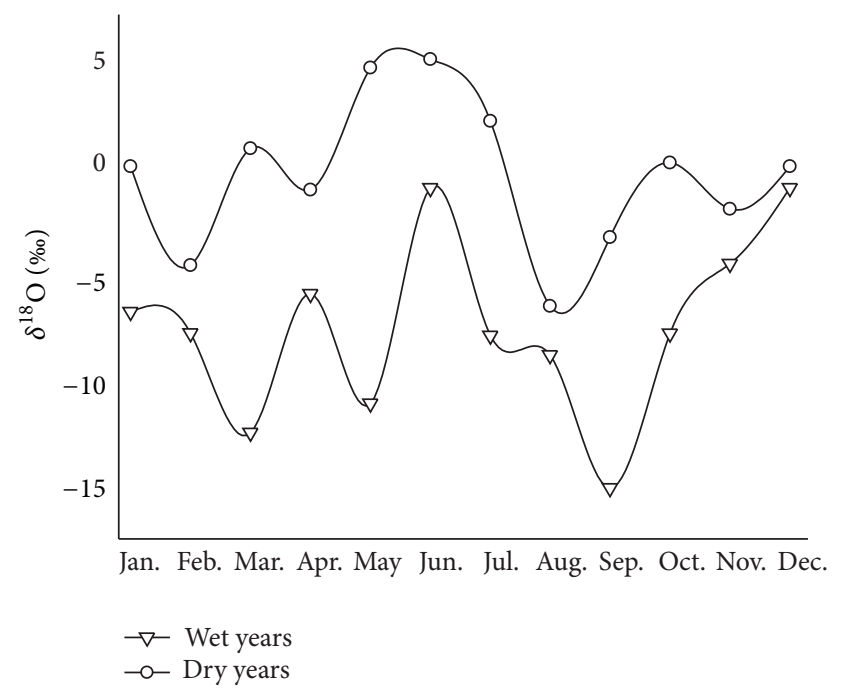

FIGURE 9: Monthly $\delta^{18} \mathrm{O}$ in dry and wet years in rainfall water of Islamabad.

remained at levels up to 4 in June and July, which suggests that there was a failure of the summer monsoon. In contrast, $\delta^{18} \mathrm{O}$ values were as low as -6 for the same months during wet years (Figure 9). A strong La Nino event prevailed during 1999-2000, which had severe effects over America, East Asia, and even Bangladesh; its effect on Pakistan was diminished by the prevailing drought $[16,21]$. The autumn season represents the time between the withdrawal of the summer monsoon and the initial stage of western disturbances where the overall water vapor flow pattern is from western Asia to Pakistan. In Figure 10(d), the water vapor traveling towards northeast Pakistan from the Indian Ocean is a prominent feature. The $95 \%$ confidence levels of water vapor fluxes were used to rectify the monthly weighted mean of rainfall water isotopes for dry and wet years in Figure 11, although the correlation 


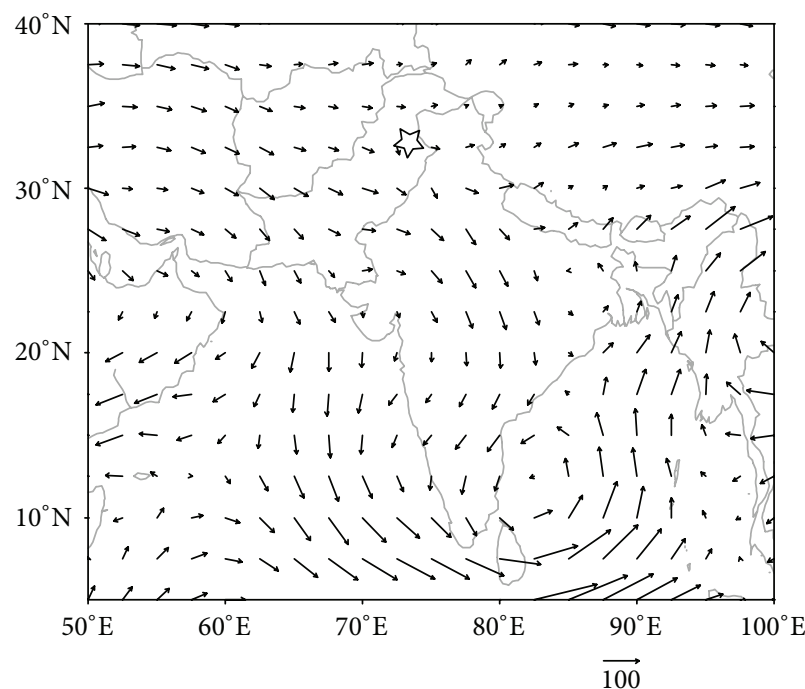

(a) DJF (anom.)

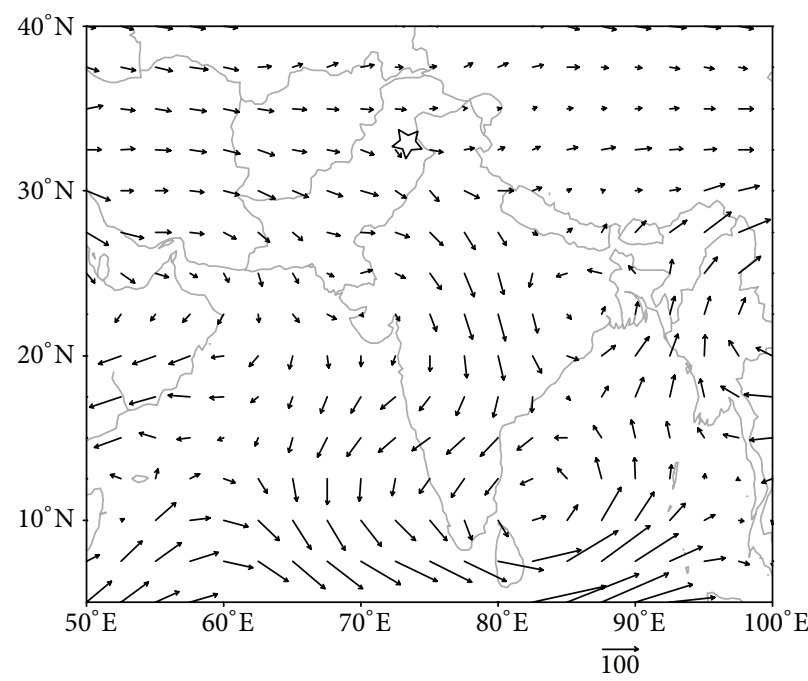

(c) JJA (anom.)

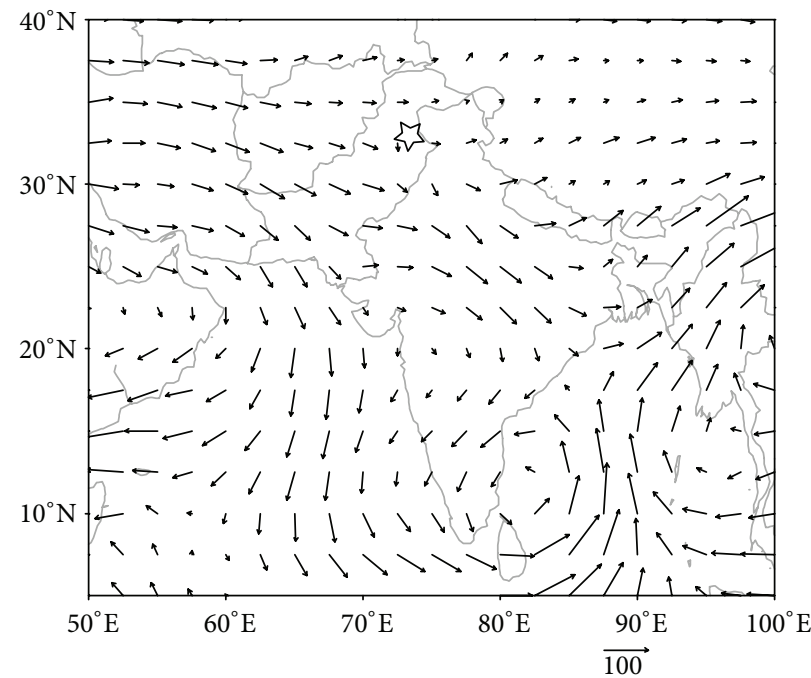

(b) MAM (anom.)

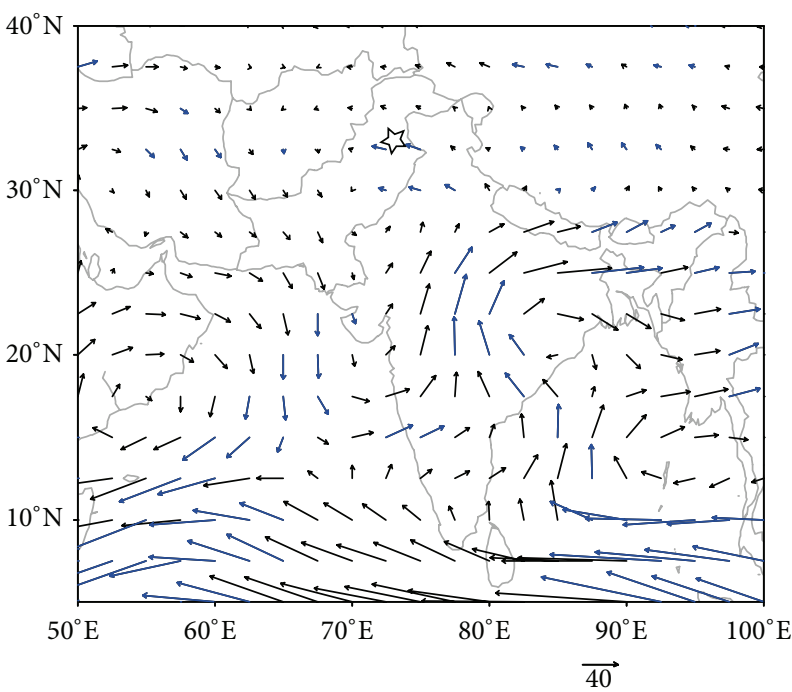

(d) SON (anom.)

FIGURE 10: Composite of the vertically integrated (a) winter, (b) spring, (c) summer, and (d) autumn water vapor fluxes $\left(\right.$ units: $\mathrm{kg} \cdot \mathrm{m}^{-1} \cdot \mathrm{s}^{-1}$ ) between wet and dry years. Blue arrows indicate that the differences between wet and dry years are significant at the $95 \%$ confidence level. A star is showing Islamabad $\left(33.65^{\circ} \mathrm{N}, 73.26^{\circ} \mathrm{E}\right)$.

coefficient in wet years was not statistically significant at the $0.5 \%$ level (Figure 11). The enrichment and depletion patterns of dry and wet years were distinctive in both Figures 9 and 10 , which confirm the potential of stable isotopes to capture metrological events effectively.

4.3. $d$-Excess in Rainfall Water of Islamabad. Deuterium excess is defined as $d=\delta^{2} \mathrm{H}-8 \delta^{18} \mathrm{O}$ [24], and it was +10 in the so-called GMWL [4], thus suggesting that evaporation from continental water bodies at low humidity can produce a vapor mass with a high $d$-excess [5]. Gat et al. [27] revealed that lower relative humidity and more evident kinetic isotope fractionation during evaporation from close basins like the Mediterranean Sea are associated with higher $d$-excess. Consequently, vapor originating from continental basins can alter the original oceanic signatures [10, 28]. Deuterium excess offers another opportunity to investigate the vapor sources. Notably, winter precipitation of Islamabad comes from the Mediterranean Sea, which has a high $d$-excess value, thus confirming the results of Gat et al. [27], who used such data to depict distinct conditions of vapor formation and additions of inland water sources during passage through inland Asia. Both pre- and postmonsoon (spring, autumn) time periods showed declining trends, but spring was associated with lower $d$-excess values than autumn because the relative humidity in Islamabad decreases continuously from January to May (Figure 12). Secondly, dry and warm spring seasons boost the reevaporation of lighter molecules $\left({ }^{2} \mathrm{H}^{1} \mathrm{H}^{16} \mathrm{O}\right)$ from raindrops with an average excess of 10 per mil increase in the deuterium excess of precipitation. More than $70 \%$ of 


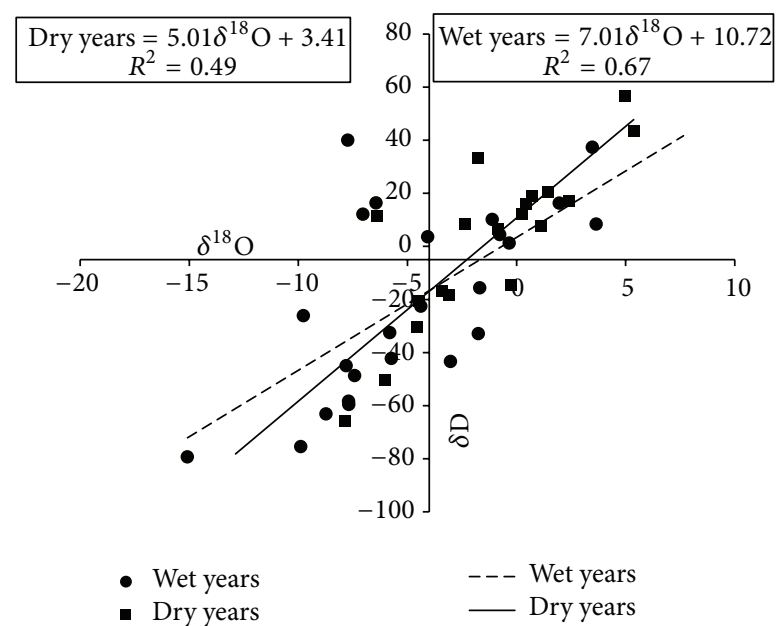

FIGURE 11: Monthly weighted means of $\delta \mathrm{D}$ and $1 \delta^{18} \mathrm{O}$ relationships for dry and wet years.

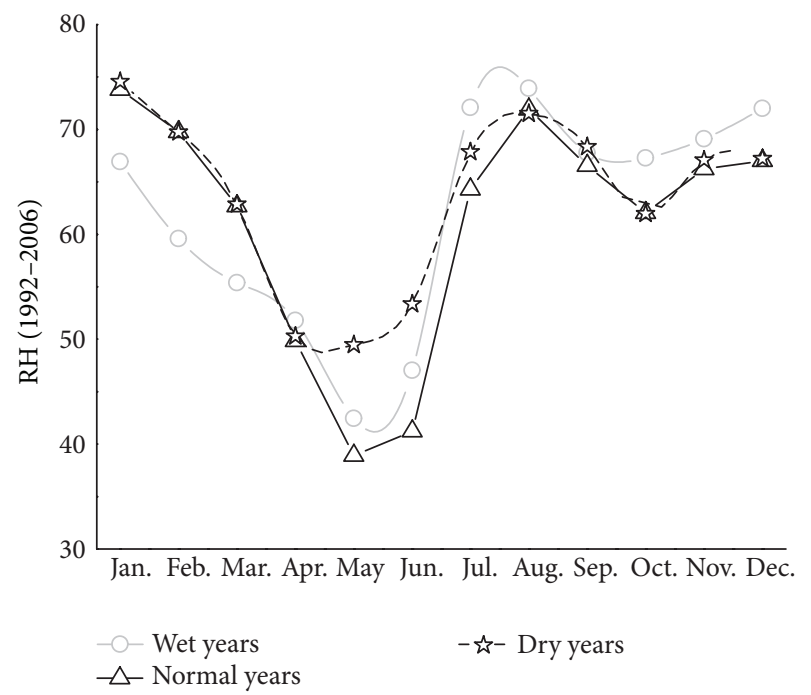

Figure 12: Monthly relative humidity (RH) of Islamabad.

the rainfall occurs during the southwest monsoon, and, in summer, the humid Indian Ocean air masses reach Islamabad along two different paths (Figure 4). The first path [1] involves air masses that originate from the Arabian Sea and travel over central India; the second path [2] involves air masses that travel along the southern Himalayas from the Bay of Bengal. The warm and humid surroundings of the Indian Ocean are the main cause for the lower $d$-excess values during the summer monsoon. Plotting the precipitation amount with $d$-excess (Figure 13), it can be seen that low precipitation amounts have variable $d$-excess values, and low precipitation amount events usually occur during the nonmonsoon season. Secondary evaporation takes place mainly during dry and warm conditions [10,31], which are more evident in dry years; even the rainfall event of more than $100 \mathrm{~mm}$ had a $d$-excess value lower than 10 . Overall, we have found that the wet years have higher $d$-excess values than dry years, thus confirming

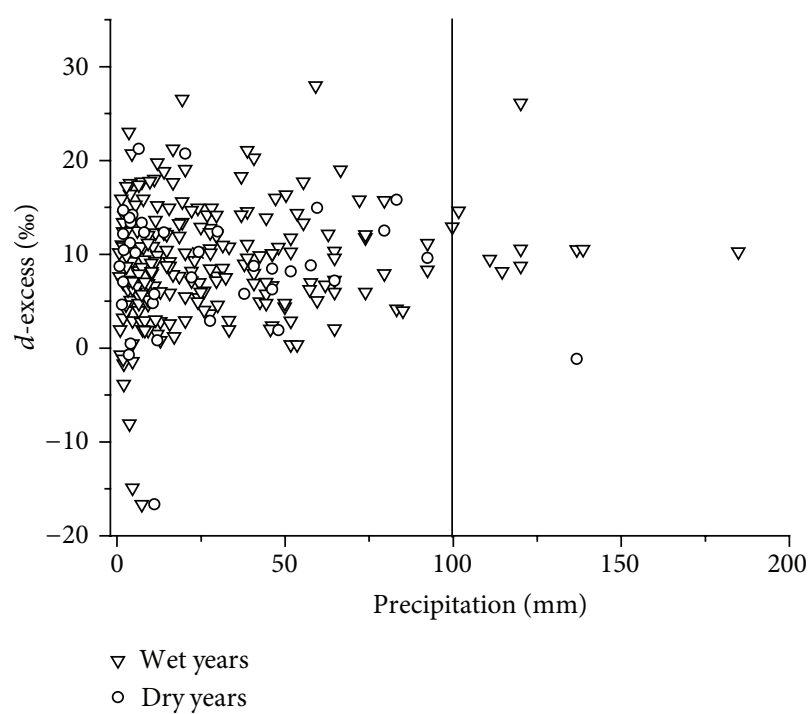

Figure 13: Dependence of $d$-excess on the rainfall amount.

that secondary evaporation took place either below the clouds or within the sampling device.

4.4. Discussion. As mentioned earlier, Pakistan falls in South Asian summer monsoon region and has semiarid to arid climatic condition except the narrow wet belt of lesser Southern Himalaya experiencing both southwest monsoon and western disturbances, including Islamabad. Temperate climatic condition, orographic effect, and seasonality along with multimoisture source bring the peculiar temporal distribution of rainfall water stable isotopes throughout the investigation period. We could not understand the water regime of Pakistan efficiently by only single GNIP station. The nearest GNIP station is in New Delhi representing the Indian monsoon region, where temperature continuously increases from January to May along with decreasing relative humidity [11]. The kinetic fractionation of the falling raindrops caused by the dry air and increasing temperature eventually leads to the gradual decrease in $d$-excess from January to May. In contrast, at Islamabad, the $d$-excess is increased from January to March, winter moisture originates from higher $d$-excess Mediterranean Sea and inland Asia [27], and long distance allows for enhanced Rayleigh distillation during transport to Islamabad. The most plausible explanation is that, due to the low ambient temperature and comparatively high relative humidity (Figures 7 and 14), the inland and secondary evaporation was absent, which masks the decrease of the $d$ excess. It has seen that reasonable high ambient temperature along with low humidity attributes the local water cycle and below cloud and inland evaporation is at peak, May and June leading the monthly least $d$-excess and highest $\delta^{18} \mathrm{O}$ in May. The available data are insufficient to explain the slight increase of $d$-excess value in June; soil moisture and inland water bodies are not at good level except for Mangla and Tarbela dams (Pakistan's two largest dams) close to Islamabad; feed by alpine glacier melting (high $d$-excess vapor) may be the dominating moisture source of the local water cycle. 

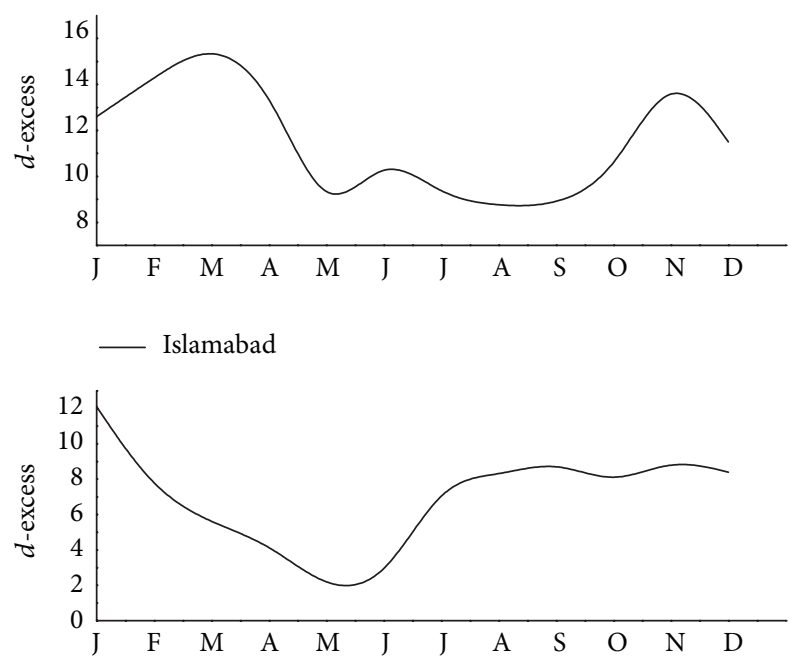

— New Delhi

FIGURE 14: Comparison of weighted monthly mean of $d$-excess of Islamabad and New Delhi.

$d$-excess value is almost +10 during the whole summer monsoon indicating the single moisture source (Bay of Bengal and Arabian Sea). Normally, in the second week of September, summer monsoon withdraws from Islamabad so we can see the increasing $d$-excess from the second week of September to the 1st week of November referring to local water cycle. Continental evaporation can produce high $d$ excess water vapor, speculation about the higher $d$-excess values of October and November and it starts to decrease in December due to low temperature. Winter moisture comes from the Mediterranean Sea and comparatively high latitude cold inland Asia to low temperature and high relative humid Islamabad makes the most depleted $\delta^{18} \mathrm{O}$ value of January and February. Though the rainout effect should be more intense at New Delhi air mass during these months, the precipitation at Islamabad had more negative $\delta^{18} \mathrm{O}$ which may be the influence of higher ambient temperature. At Islamabad $\delta^{18} \mathrm{O}$ is continuously increasing from January to May following the temperature and decreasing relative humidity.

Western disturbance withdrawal accompanied with dry and hot continental water vapor abruptly increases (about $7 \%$ ) $\delta^{18} \mathrm{O}$ in March to May next to less monthly rainfall amount. $\delta^{18} \mathrm{O}$ is gradually decreased from May to August showing the total depletion of $6 \%$; correspondingly, rainfall increases and reached a maximum in July (Figure 6); it shows a month delay between the rainfall and $\delta^{18} \mathrm{O}$ zenith. Empirical "amount effect" can explain $\delta^{18} \mathrm{O}$ depletion but would not explain the delay factor, suggesting the contribution of other factors to further depletion of precipitation at our site, although we have found "amount effect" as a dominant factor in dry and wet years for short period (Figure 9), for annual long-term period temperature is the most dominant factor controlling $\delta^{18} \mathrm{O}$ (Table 2).
The isotopes depleted rivers discharge is at peak in July and August both in Arabian Sea [32] and Bay of Bengal [33] which would affect the isotopic ratio of surface water and after mid-August the major part of vapor comes from Bay of Bengal and relatively long distance from our site enhances the "continental effect." The movement of cyclonic disturbance location in Bay of Bengal from $20 \mathrm{~N}$ to $15 \mathrm{~N}$ caused more faction of moisture on long way which would make more depleted vapor due to possible rainout effect [12]. Central India (Chhattisgarh, Madhya Pradesh, and Haryana) receives more precipitation in August than in July which may enhance the rainout effect on August precipitation of Islamabad.

The heaviest rainfall event $\left(\delta^{18} \mathrm{O}-4.08, \delta \mathrm{D}-28.65\right)$ of the last century [16] could not be explained by available data. The stronger Bay of Bengal storm and arrival of water vapor from South China Sea bring about more depleted precipitation to Islamabad during wet years reflecting the continental effect; these are weaker or negligible during dry years ultimately nearer to Arabian Sea which brings comparatively enriched water vapor to our site. The significant change of $\delta^{18} \mathrm{O}$ after mid-September with decreasing rainfall amount and intensity would be the recycle of previous months rainfall and change in moisture source from marine to continent, which is caused by shifting of southwest monsoon. After midNovember, temperature goes down and hit a minimum value in January along with the arrival of western disturbances which makes the most depleted $\delta^{18} \mathrm{O}$. Unfortunately, we have only one station piece of data which may limit our results to represent the accurate situation.

\section{Conclusion and Future Work}

The first detailed interpretation of 15 years (1992-2006) of IAEA/GNIP data and meteorological data for Islamabad representing the narrow humid belt of Pakistan shows that the LMWL $\delta \mathrm{D}=7.89 \delta^{18} \mathrm{O}+11.05$ and the $d$-excess varied from -20 to 32 . A total of $72 \%$ of the annual precipitation's isotopic signature was dependent on the rainfall amount, and temperature controlled $73 \%$ of the isotopic features during October to May.

Long-term annual multicorrelations show $60 \%$ of $\delta^{18} \mathrm{O}$ directly related to temperature; on the other hand, $48 \%$ and $50 \%$ of $\delta^{18} \mathrm{O}$ were inversely indirectly related to precipitation and humidity correspondingly. It can be concluded that longterm trend of rainfall water isotopes for Islamabad is in agreement with the so-called GMWL, but large differences were found between wet and dry years and among the different seasons. Warm and humid conditions associated with the Indian Ocean result in isotopes enriched water vapor, and secondary evaporation was more apparent during dry years, although some influence was apparent from depleted Himalayan river inflow entering the northern Bay of Bengal. In wet years, the South China Sea and Bay of Bengal branch brought more precipitation to the southwestern Himalayas (Islamabad) leading to depleted isotopes value. Unfortunately, the current coverage of the IAEA/GNIP database in Pakistan is incomplete [34]. Most enriched and depleted $\delta^{18} \mathrm{O}$ values were found in June 2006 due to hot and the least rainfall 
and August 1995 following above-normal and convective rainfall. Spatial and temporal limitations of data are the main constraint to explain the unusual precipitation events as last century's heaviest rainfall event occurred on 23 July 2001 [16]. Additional large-scale spatial and temporal investigations of the rainfall water isotope composition for Pakistan are crucial in order to determine the sources and controlling factors of precipitation. Such information would enhance understanding of the regime of water cycle and controlling factors.

\section{Conflict of Interests}

The authors declare that there is no conflict of interests regarding the publication of this paper.

\section{Acknowledgment}

This research was supported by CAS-TWAS president fellowship under Grant no. 05Z55105F4.

\section{References}

[1] K. Ullah and S. T. Gao, "Moisture transport over the Arabian Sea associated with summer rainfall over Pakistan in 1994 and 2002," Advances in Atmospheric Sciences, vol. 29, no. 3, pp. 501508, 2012.

[2] R. A. Houze Jr., D. C. Wilton, and B. F. Smull, "Monsoon convection in the Himalayan region as seen by the TRMM Precipitation Radar," Quarterly Journal of the Royal Meteorological Society, vol. 133, no. 627, pp. 1389-1411, 2007.

[3] S. Chidambaram, M. V. Prasanna, A. L. Ramanathan et al., "A study on the factors affecting the stable isotopic composition in precipitation of Tamil Nadu, India," Hydrological Processes, vol. 23, no. 12, pp. 1792-1800, 2009.

[4] H. Craig, "Isotopic variations in meteoric waters," Science, vol. 133, no. 3465, pp. 1702-1703, 1961.

[5] J. R. Gat and I. Carmi, "Evolution of the isotopic composition of atmospheric waters in the Mediterranean Sea area," Journal of Geophysical Research, vol. 75, pp. 3039-3048, 1970.

[6] J. Liu, G. Fu, X. Song et al., "Stable isotopic compositions in Australian precipitation," Journal of Geophysical Research D: Atmospheres, vol. 115, no. 23, Article ID D23307, 2010.

[7] K. Rozanski, S. J. Johnsen, U. Schotterer, and L. G. Thompson, "Reconstruction of past climates from stable isotope records of palaeo-precipitation preserved in continental archives," Hydrological Sciences Journal, vol. 42, no. 5, pp. 725-745, 1997.

[8] C. Unnikrishnan Warrier and M. Praveen Babu, "A study on the spatial variations in stable isotopic composition of precipitation in a semiarid region of Southern India," Hydrological Processes, vol. 26, no. 25, pp. 3791-3799, 2012.

[9] T. Yamanaka, J. Shimada, Y. Hamada et al., "Hydrogen and oxygen isotopes in precipitation in the northern part of the North China Plain: climatology and inter-storm variability," Hydrological Processes, vol. 18, no. 12, pp. 2211-2222, 2004.

[10] P. K. Aggarwal, "Isotope hydrology at the International Atomic Energy Agency," Hydrological Processes, vol. 16, no. 11, pp. 22572259, 2002.
[11] P. S. Datta, S. K. Tyagi, and H. Chandrasekharan, "Factors controlling stable isotope composition of rainfall in New Delhi, India," Journal of Hydrology, vol. 128, no. 1-4, pp. 223-236, 1991.

[12] S. Sengupta and A. Sarkar, "Stable isotope evidence of dual (Arabian Sea and Bay of Bengal) vapour sources in monsoonal precipitation over north India," Earth and Planetary Science Letters, vol. 250, no. 3-4, pp. 511-521, 2006.

[13] IAEA (International Atomic Energy Agency), Global Network of Isotopes in Precipitation: The GNIP Database, 2001, http://isohis.iaea.org.

[14] Q. Z. Chaudhry and G. Rasul, "Agroclimatic classification of Pakistan," Science Vision, vol. 9, no. 1-4, pp. 59-66, 2003.

[15] R. A. Houze Jr., "Orographic effects on precipitating clouds," Reviews of Geophysics, vol. 50, no. 1, 2012.

[16] G. Rasul, Q. Chaudhry, S. Zhao, and Q. Zeng, "A diagnostic study of record heavy rain in twin cities Islāmābad-Rāwalpindi," Advances in Atmospheric Sciences, vol. 21, no. 6, pp. 976-988, 2004.

[17] S.-Y. Wang, R. E. Davies, W.-R. Huang, and R. R. Gillies, "Pakistan's two-stage monsoon and links with the recent climate change," Journal of Geophysical Research D, vol. 116, no. 16, Article ID D16114, 2011.

[18] L. Tian, T. Yao, J. W. C. White, W. Yu, and N. Wang, "Westerly moisture transport to the middle of Himalayas revealed from the high deuterium excess," Chinese Science Bulletin, vol. 50, no. 10, pp. 1026-1030, 2005.

[19] M. Hanif, A. H. Khan, and S. Adnan, "Latitudinal precipitation characteristics and trends in Pakistan," Journal of Hydrology, vol. 492, pp. 266-272, 2013.

[20] W. Köppen, E. Volken, and S. Brönnimann, “The thermal zones of the earth according to the duration of hot, moderate and cold periods and to the impact of heat on the organic world," Meteorologische Zeitschrift, vol. 20, no. 3, pp. 351-360, 2011.

[21] IWMI, "Drought mitigation in Pakistan: current status and options for future strategies," Working Paper Drought Series 3.K, International Water Management Institute, 2004.

[22] E. Kalnay, M. Kanamitsu, R. Kistler et al., "The NCEP/NCAR 40-year reanalysis project," Bulletin of the American Meteorological Society, vol. 77, no. 3, pp. 437-471, 1996.

[23] International Atomic Energy Agency (IAEA), "Statistical treatment of environmental isotope data in precipitation," Technical Report Series 206, International Atomic Energy Agency, Vienna, Austria, 1981.

[24] W. Dansgaard, "Stable isotopes in precipitation," Tellus, vol. 16, no. 4, pp. 436-468, 1964.

[25] H. Achyuthan, R. D. Deshpande, M. S. Rao et al., "Stable isotopes and salinity in the surface waters of the Bay of Bengal: implications for water dynamics and palaeoclimate," Marine Chemistry, vol. 149, pp. 51-62, 2013.

[26] G. B. Pant and K. R. Kumar, Climates of South Asia, John Wiley \& Sons, Chichester, UK, 1997.

[27] J. R. Gat, B. Klein, Y. Kushnir et al., "Isotope composition of air moisture over the Mediterranean Sea: an index of the air-sea interaction pattern," Tellus B, vol. 55, no. 5, pp. 953-965, 2003.

[28] J. R. Gat, C. J. Bowser, and C. Kendall, "The contribution of evaporation from the Great Lakes to the continental atmosphere: estimate based on stable isotope data," Geophysical Research Letters, vol. 21, no. 7, pp. 557-560, 1994.

[29] K. Rozanski, L. Araguás-Araguás, and R. Gonfiantini, "Isotopic patterns in modern global precipitation," in Climate Change in Continental Isotopic Records, International Atomic Energy Agency, 1992. 
[30] G. A. Meehl and W. M. Washington, "South Asian summer monsoon variability in a model with doubled atmospheric carbon dioxide concentration," Science, vol. 260, no. 5111, pp. 1101-1104, 1993.

[31] H. Peng, B. Mayer, S. Harris, and H. R. Krouse, "The influence of below-cloud secondary effects on the stable isotope composition of hydrogen and oxygen in precipitation at Calgary, Alberta, Canada," Tellus B, vol. 59, no. 4, pp. 698-704, 2007.

[32] A. Karim and J. Veizer, "Water balance of the Indus River Basin and moisture source in the Karakoram and western Himalayas: implications from hydrogen and oxygen isotopes in river water," Journal of Geophysical Research: Atmospheres, vol. 107, no. 18, pp. ACH 9-1-ACH 9-12, 2002.

[33] S. F. M. Breitenbach, J. F. Adkins, H. Meyer, N. Marwan, K. K. Kumar, and G. H. Haug, "Strong influence of water vapor source dynamics on stable isotopes in precipitation observed in Southern Meghalaya, NE India," Earth and Planetary Science Letters, vol. 292, no. 1-2, pp. 212-220, 2010.

[34] M. Vuille, R. S. Bradley, M. Werner, R. Healy, and F. Keimig, "Modeling $\delta^{18} \mathrm{O}$ in precipitation over the tropical Americas: 1. Interannual variability and climatic controls," Journal of Geophysical Research D: Atmospheres, vol. 108, no. 6, article 4174, 2003. 

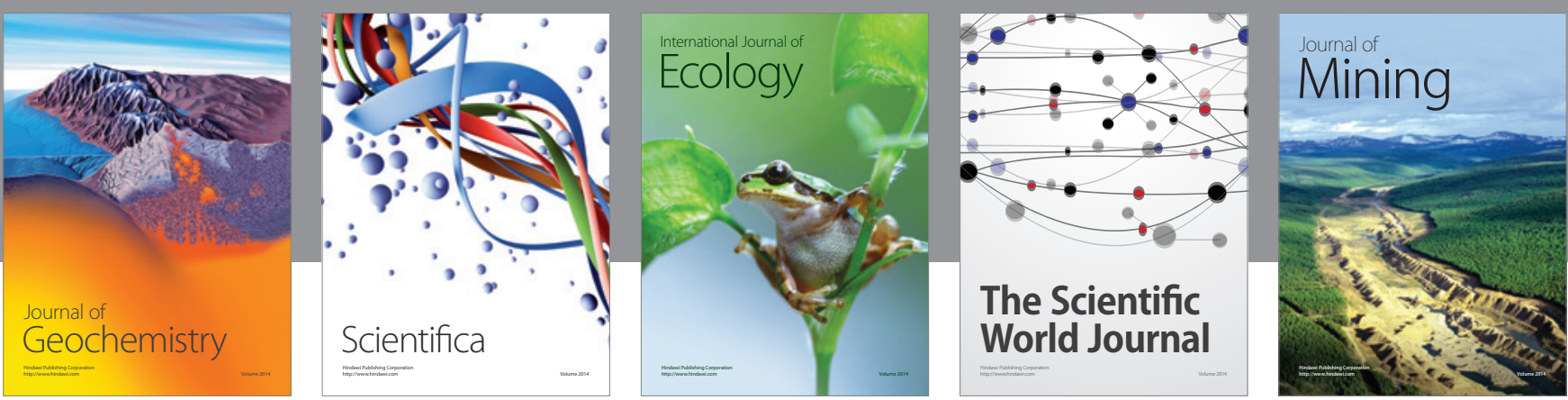

The Scientific World Journal
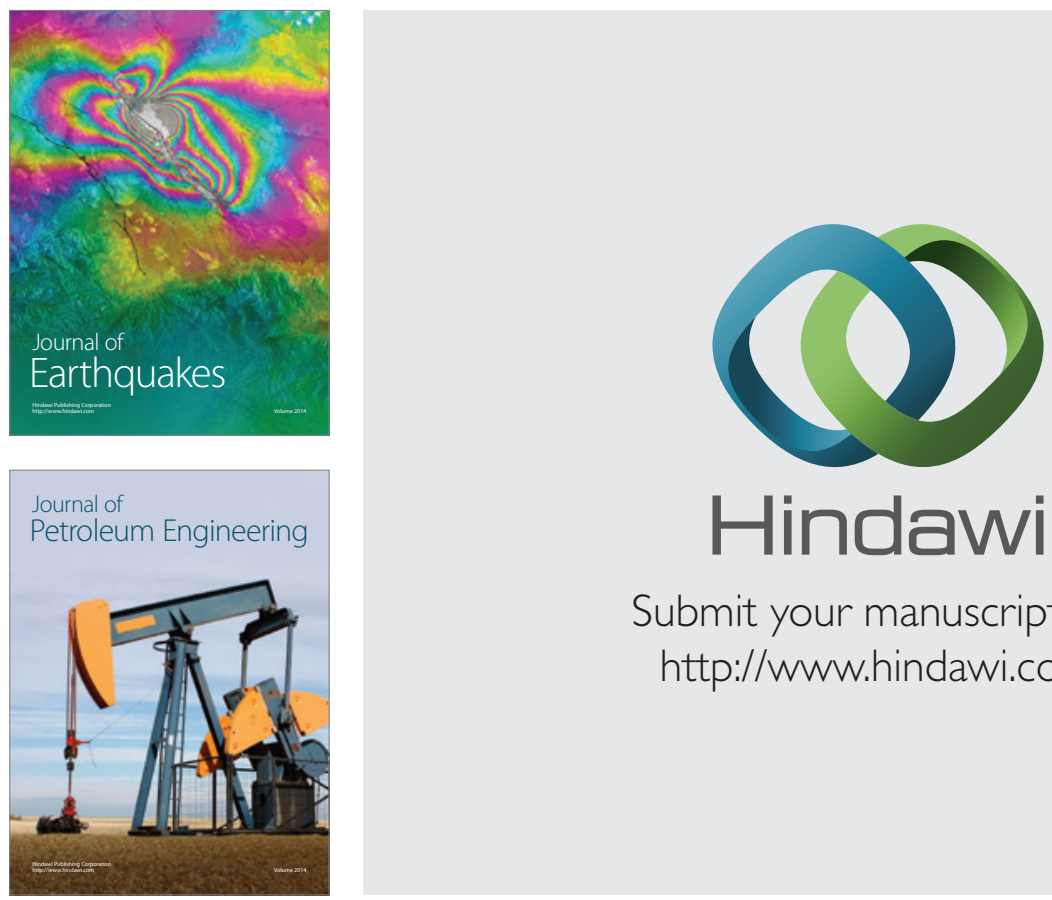

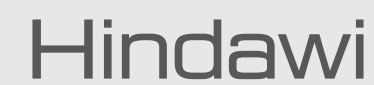

Submit your manuscripts at

http://www.hindawi.com
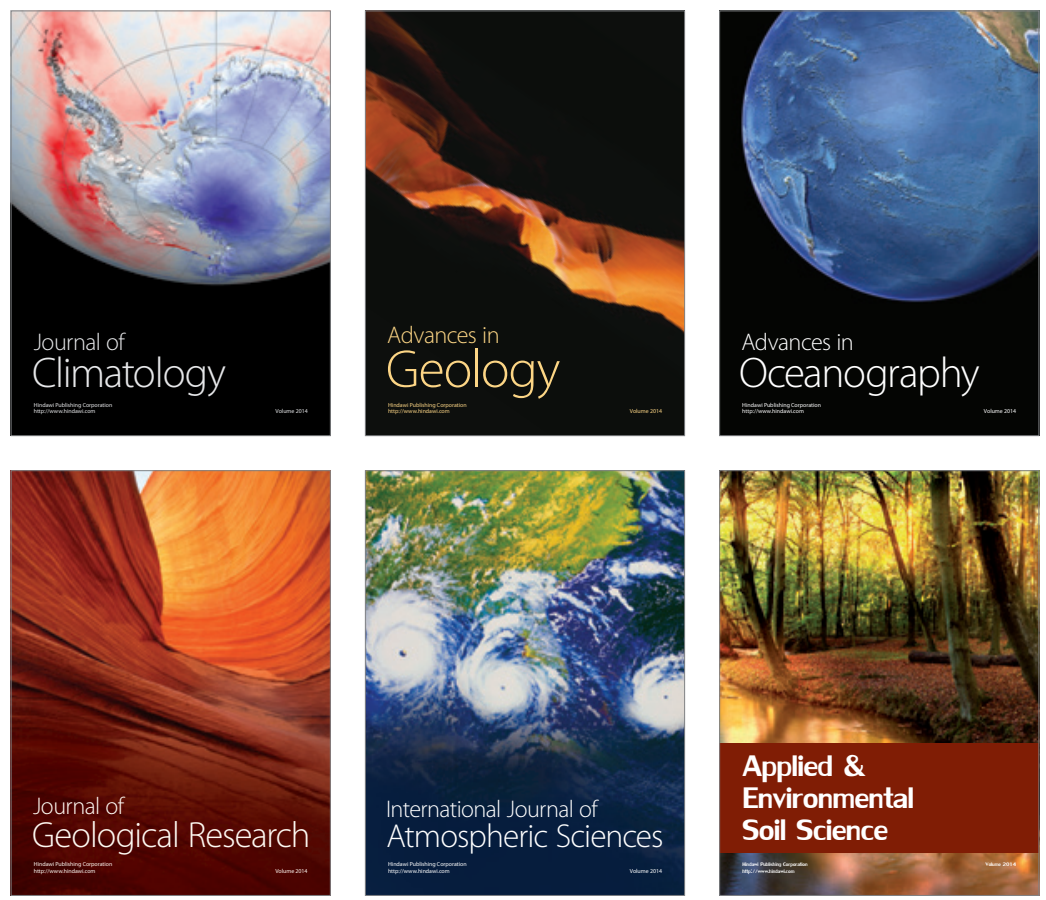
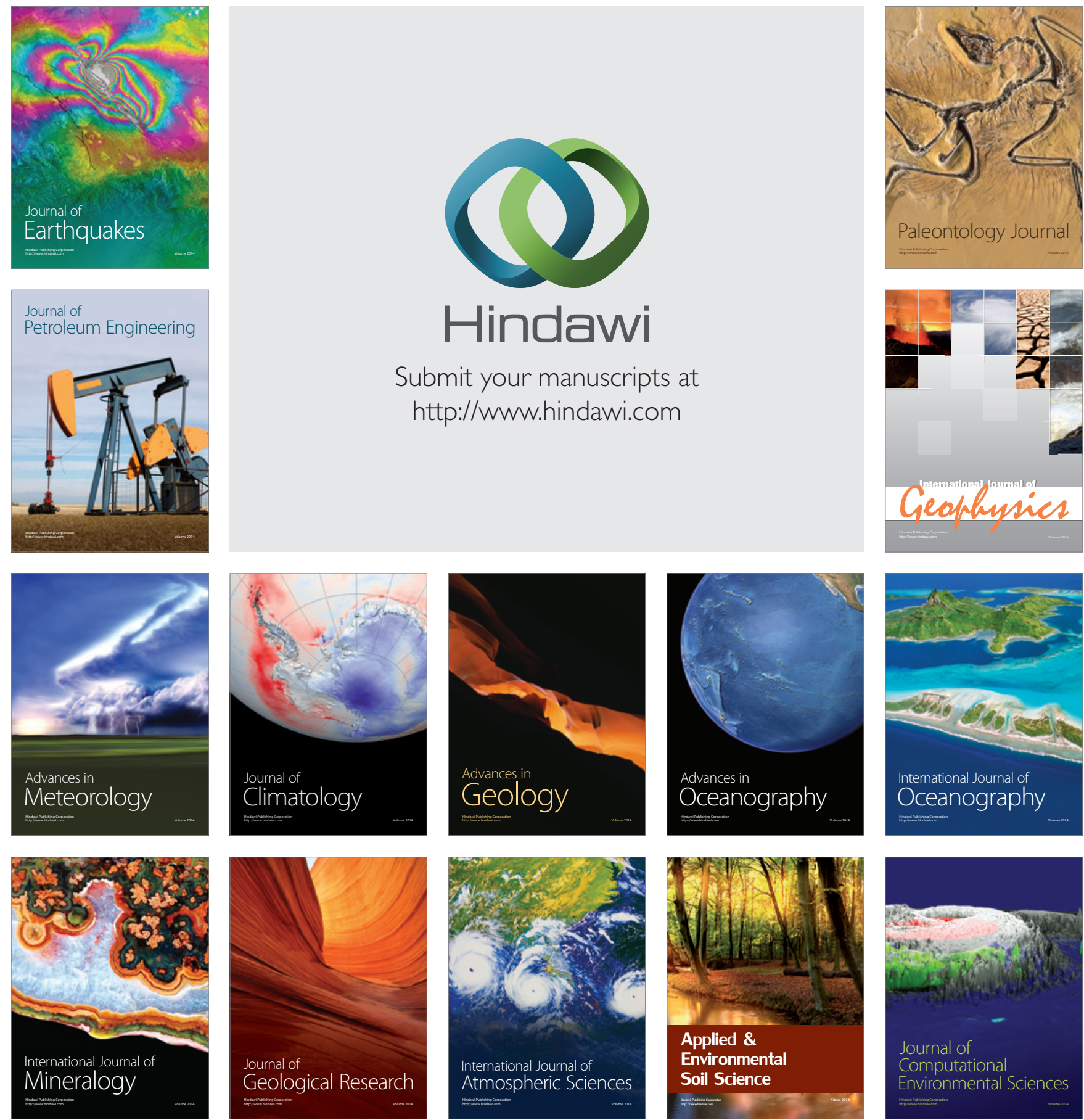